\title{
"ROLE" AS AN INTERACTIONAL DEVICE
}

\section{TIMOTHY HALKOWSKI}

Reprinted from SOCIAL PROBLEMS

Volume 37, Number 4, November 1990

Copyright (C) 1990 by the Society for the Study of

Social Problems, Inc. 


\title{
"Role" as an Interactional Device*
}

\author{
TIMOTHY HALKOWSKI, University of Kentucky
}

This paper reports on an aspect of the social organization of interaction, namely, the use by interactants of the concept "role." In contrast with traditional social scientific uses of the concept as an explanatory resource in the analysis of social action, I propose that interactants use this concept to make sense of as well as accomplish-actions and activities in the social world. Analysis of segments of conversation taken from videotapes of the Iran-Contra Congressional hearings demonstrate this as well as the more general point that description is a form of social action.

Ko-Ko: Now, as my Solicitor, how do you advise me to deal with this difficulty? Pooh-Bah: Oh, as your Solicitor, I should have no hesitation in saying "chance it--" Ko-Ko: Thank you. I will.

Pooh-Bah: - If it were not that, as Lord Chief Justice, I am bound to see that the law isn't violated. Ko-Ko: I see. Come over here where the Chief Justice can't hear us. (They cross the stage.)

The Mikado (W.S. Gilbert 1917:13)

The concept "role" has a long history in the social sciences. Introduced into sociology by Mead (1934) and Linton (1936), role has been a central concept in the work of diverse theorists (e.g., Parsons 1951, 1968; Merton 1957, 1968; Turner 1962; Blumer 1969; Stryker-1980; Goffman 1959). Moreover, virtually every introductory sociology textbook notes that long before it was a sociological concept, role was used as a vernacular term by members of society. Many texts even provide a quotation from Shakespeare to help make this point:

All the world's a stage,

And all the men and women merely piayers.

They have their exits and their entrances;

And one man in his time plays many parts.

As You Like It, Act II, Scene 7

However, most texts then move on to distinguish and discuss the related sociological concepts of role-sets, status, role conflict, and role strain.

This paper gives detailed attention to the prior point, namely, that the concept "role" is, first and foremost, a "social invention" (Coleman 1970) used by members of society. I draw on video-taped segments of interaction to demonstrate how interactants use role to accomplish two interactional tasks, issuing and avoiding an accusation, and suggest how this re-location of role can lead to productive insights into the organization of social interaction. The point is to broaden our understanding of role beyond its use as an analytic, or second-order (Schutz 1982:59), concept, used by professional social scientists, to include an appreciation of how members use it as an interactional device in their everyday lives.

* A version of this paper was presented at the 1990 Annual Meetings of the American Sociological Association in Washington, D.C. I would like to thank Deirdre Boden. Steven Clayman, Anthony Giddens, Douglas Maynard, Thomas Wilson, and Don Zimmerman for their advice and suggestions on earlier drafts of this paper. I would also like to thank the anonymous reviewers of Sacial Problems for their insightful comments. This work was completed while the author was a National Institute of Mental Health postdoctoral fellow, Grant Number MH15730. Correspondence to: Department of Behavioral Science, College of Medicine, University of Kentucky, lexington, KY 40536-0086. 


\section{"Role" in Social Theory and Everyday Life}

Role is used in the social sciences to refer to the set of behaviors appropriate to a particular social position or status. Linton (1936) proposed that the "rights and duties" that constitute status are put into effect through one's role performance. Social order is thus explained by reference to the sets of interlocking social positions in society (e.g., wife-husband, employeremployee) and the rights and duties those who occupy these positions have toward each other (Parsons 1968; cf. Hilbert 1981, forthcoming; Giddens 1984:83-84).

Turner (1962) criticized this functionalist conception of role and proposed an interactionist account of how roles are organized, and in turn, how they organize the social world. Instead of treating role performance as the indifferent enactment of rights and duties prescribed for a particular status, Turner argued that role behavior is actively produced by people in interaction.

While both functionalist and interactionist approaches use role as an analytic tool to account for social ordex, members of society invented the concept of "role" as a useful, practical part of their language. As employed by members, the concept and conception of role allow for a distinction between a person and a "slot" in an organization (Coleman 1970:163) or some organized setting (see Kantorowitz 1957). And Dorothy Smith (1974:44), drawing on Marx, has noted:

Marx's example instructs us not to treat a concept as a theoretical primitive, in the logical sense, nor as interpretable solely in terms of other concepts. Rather, a concept requires to be discovered again in the actualities of what living people do. ... Take ... a very ordinary piece of sociological currency, the concept of role... This concept could not be thought unless men already knew how to make a separation between person and role as a practical accomplishment.

Rather than treating "role" as a self-evident, social-scientific resource for analysis, and following work by Garfinkel (1967) and Zimmerman and Pollner (1970), social scientists should take it as a topic of study. Doing so will help illuminate how interactants organize the social world by their use of these conceptions and actions (Schutz 1962:59; Sacks 1984).

Such a transformed way of analyzing "role" has been proposed by Hilbert (1981, forthcoming). After a powerful critique of the logical and practical possibility of "literal role prescription," Hilbert (1981:216-17) offers an empirically grounded, alternative view:

Our recommendation is to view "role" as an organizing concept used on occasion by actors in social settings, and to view its utility for actors in terms of what they can do with it; i.e., the work they require it to do, in sustaining the perceived stability of social behavior, whatever their immediate purposes. Viewed this way, roles are not behavioral matrices to be described and explained but are conceptual resources actors use to clear up confusion, sanction troublemakers, instruct others in the ways of the world, and so forth.

In a similar vein, Goffman (1981:145) pointed out that a speaker can "alter the social role in which he is active ... what in committee meetings is called 'changing hats.' ... [T] select the capacity in which we are to be active is to select (or to attempt to select) the capacity in which the recipients of our action are present." 1

\section{Analysis: "Mister Meese" vs. "the Attorney General"}

The data I use are transcriptions of videotapes of the Iran-Contra Congressional hearings, which were broadcast on television in the summer of 1987 (see also, Halkowski 1990). These transcripts are useful for exploring how interactants use the concept of role since much of their talk concerns people's actions and how they should be seen.

1. See also, Maynard (1984:55-76) and Clayman (1988). 
Consider the following: ${ }^{2}$

\section{Excerpt I [IC:dt.14]}

$\mathrm{CC}=$ committee counsel (Mr. Nields)

$\mathrm{W}=$ witness (Lt. Col. Oliver North).

CC: =are you he:re telling thuh committee. (.hh)

that y:ou don't remember. (.hh)

Whether on November twenny first there was a

document in your files reflecting presidential

approval of the diversion.

(0.8)

W: As a matter of fact I'll tell you specifically

that I thought they were all go:ne.

(0.3)

Because by thuh time I was to:ld

(0.5)

that some point early on November twenny first

(0.3)

that there would be an INnquiry.

Conducted by:: (.) Mister Meese,

(0.6)

I assured (0.3) Admiral Poindexter

(0.2)

incorrectly it- it see:ms,

that $A:: L L$ (.) of those documents no longer

existed.

(0.2)

and so that is EARrly $(0.3)$ on November

twennyfirst,

(0.2)

because I believe the decision (0.3) to make an

inquiry

(.)

to have thee Attornally-Attorney General

(0.4)

or Mister Meese in his ro:le as friend ta thuh

President.

(0.3)

conduct a fact finding excursion,

on what happened in September an November in

Nineteen Eighty F:I:VE,

(0.6)

$\mathfrak{I}$ assured the Admiral,

(0.3)

don't worry, (0.4) its a:ll taken care of.

(0.2)

CC: You('d) all [ ready shredde $]^{d}$ 'em.

W:

(0.2)

W: That's right. ((continues turn))

2. In the data segments, brackets indicate overlapping talk by two or more speakers. Inbreaths are indicated by (.h), exhalations by (h). Underlining is used to indicate emphasis: Capitalization is used to represent loudness. Punctuaion, with periods indicating falling intonation, commas indicating "continuing" intonation (i,e., slight rise), and question marks indicating rising intonation. Equal signs indicate utterances whích are "latched," or produced one immediately after the other. Colons indicate a sound stretch, and numbers in parentheses indicate silence in tenths of seconds. Lastly, ${ }^{*}$ is used to mark talk that is produced softly and quietly. For a more complete list of transcription conventions, see Atkinson and Heritage (1984). 
Note that in the first part of the answer turn, the witness references "Mister Meese," (line 15). In a subsequent portion of the turn, the witness references "thee Attornally", then cuts off this utterance, as represented by the hyphen (line 29). He then produces the self-correction, "Attorney General" (see Schegloff, Jefferson, and Sacks 1977). After this self-correction ("Attorney General"), the speaker pauses for 0.4 seconds, and then produces a "contrast marker" ("or"), which is used to introduce another repair: "Mister Meese in his ro:le as friend ta thuh President" (lines 31-32).

Note that the witness produces three different formulations of a particular individual: "Mister Meese"; "thee Attorney General"; and "Mister Meese in his role as friend to the President." Furthermore, the first reference is left to stand as adequate, while the second one is twice self-corrected by the speaker. The first correction repairs a "production error": the witness mispronounces "Attorney" as "Attornally." The second repair is a "reference repair," in which the witness drops the prior reference term, "the Attorney General," and substitutes another, "friend to the President."

One thing to notice here is what the speaker is doing interactionally by replacing the second reference term with the third. Prior research has shown that people routinely use descriptions to accomplish interactional tasks (Sacks 1972a, 1972b, 1979). As Schegloff (1988a:19) put it, "Descriptions are inspected by co-participants to see what their speaker is doing by talking in that way, by describing in that way. Describing is a vehicle for acting." And Maynard (1984:119-38) has shown how person descriptions are used to do various interactional tasks in plea bargaining:

Defendants' attributes are used to the extent that they can support proposals, position-reports, and their replies in actual negotiations over dispositions. More generally, when persons are talked about in any conversation, descriptions are selected and produced according to what activities are being done.

Similar examples have been noted in analyses of interaction within British Tribunals (Atkinson and Drew 1979), news interviews (Clayman 1987:120-35), Thai criminal trials (Moerman 1988), and group therapy sessions involving "juvenile offenders" (Sacks I979).

When the speaker in the present case repairs the second reference term, "Attorney General" (line 29), he doesn't simply replace it with the first (apparently adequate) reference term, "Mister Meese" (line 15). Instead, he replaces it with "Mister Meese in his ro:le as friend ta thuh President" (lines 31-32). In what follows I consider specifically what the witness is doing in these repairs.

\section{Membership Categorization Devices}

When the witness refers to "Mister Meese," he uses what conversation analysts call a "recognitional" term (Sacks and Schegloff 1979). Using a recognitional assumes that the hearer will recognize the person so named. The term "thee Attorney General," by contrast, is a category, specifically a "membership category" (Sacks 1972a, 1972b). Interactants use mem. bership categories to classify one another. As a property of their use, categories are grouped in sets or "devices" that can be discovered empirically (Sacks 1972a:430, note 5). For example, in this culture there are the categories catcher, first baseman, and pitcher, and they belong to the device "baseball team" (Sacks 1972a, 1972b). Similarly, interactants can treat the category "the Attorney General" as belonging to the device "cabinet members" or "law enforcement officers."

In addition, Sacks (1972b:335-37) demonstrated that for membership categories there are activities that people in interaction treat as bound to the category in question. These "category bound activities" can be used by interactants to invoke a particular categorization device without specifically naming it. 
With the first reference term he uses, "Mister Meese" (line 15), the witness uses a recognitional, which displays his orientation to his hearers as others who will know who he is speaking of. In the witness's second reference (line 29), he uses a membership category: "thee . . Attorney General". In his last reference (lines 31-32), he reproduces the same recognitional used earlier, but appends to it a new membership categorical (MC) phrase:

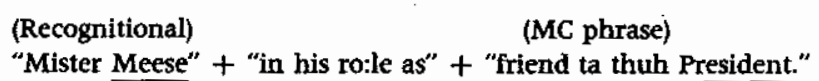

Why does the witness refer to the same person three different ways?

Sacks (1963) and Garfinkel (1967) have noted that there are many possible correct ways to reference any particular object, person, or place. Given this, members cannot simply produce the correct description; rather, a correct description must be selected from a relevant set of terms. Sacks (1972a:329; and see Schegloff 1988a) referred to this as the problem of relevance and in doing so he demonstrated that "an examination of instances of members' describings" is central to the question of "how sociologists might solve their own problem of constructing descriptions."

With the availability of many different categorization devices (e.g., the device "family," containing the categories "father," "mother," "son," "daughter"; the device "sex," containing the categories "male" and "female"; the device "cabinet member," containing the categories "Secretary of the Treasury," "Secretary of Defense," "Secretary of Education, "Attorney General," etc.), how does the witness decide which way to refer to the person in question?

One choice the witness made was simply to use a recognitional or name, as in line 15's "Mister Meese." This solves the possibly difficult problem of deciding which membership categorization device is appropriate, a decision that can have significant interactional consequences and is in no sense simply given by the details of the setting. As Sacks (1972a:36) pointed out, "The reproducibility of any categorization, whether done by members or by sociologists, requires ... some method whereby the selection of the categorization device(s) to be used in making that categorization may be reproducibly provided for." In other words, members have systematic methods for choosing a categorization device. In addition, when a speaker categorizes someone, hearers can and will perform an operation on that category so as to find the device from which that category was used. By employing a particular membership category, a speaker thus provides a resource through which others can figure out how to fit the referenced person into the talk-so-far. By using these categorization devices to reference persons, interactants make their talk understandable (Sacks 1972a, 1972b).

Note that the first reference term ("Mister Meese" line 15) does not implicate a categorization device, while the second ("thee ... Attorney General" line 29) and third ("Mister Meese in his ro:le as friend ta thuh President" lines 31-32) $\mathrm{do}^{3}$ In addition, the first reference term stands alone in its sequential environment, whereas the second and third are in close proximity (the third being a replacement for the second).

Reconsider a segment from excerpt one, noting the use of different action descriptions for Meese's task. The witness changes his original description of the work that Meese was to do:

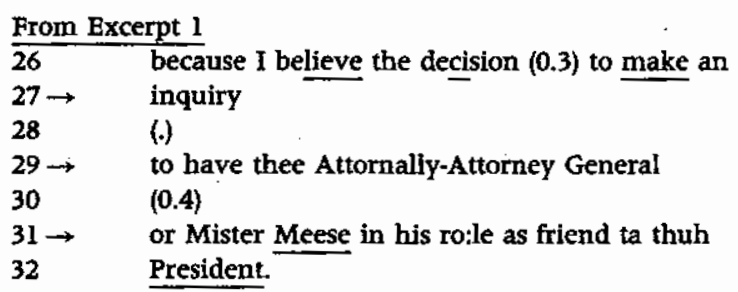

3. "Friend" is a category from the device "relational pair" (see Sacks 1972a); and ". . friend ta thuh President" is a membership category that implicates the device "relation to the President": "friend"/"not friend". 
This work is first referred to as an "inquiry," then it is referred to as a "fact finding excursion" (lines 27, 34). ${ }^{4}$ This repair of the action description is done in the immediate sequential environment of the repair of person-reference I considered earlier. With his person-reference repairs, as well as with his action-description repairs, the witness is shifting from one categorization device to another; from devices that might be implicated by the categorizations "Attorney General" and "inquiry," and repairing those referents with categorizations that implicate the device "relation to the President." With these descriptions the witness makes Meese and his actions seeable as non-official. The witness thereby also proposes a description for his own actions. While he might be seeable as having destroyed documents that were being sought by "the Attorney General," he refers to Meese as a "friend of the President." Depending on which description of Meese and his action prevails, the witness either impeded an internal "fact finding excursion" or was involved in the "obstruction of justice" and the destruction of evidence needed by an official inquiry.

\section{Category/Device Shifting}

Recall that when the reference term "Mister Meese" is first used (line 15), it is the only reference to him in that turn constructional unit (lines 9.21; Sacks, Schegloff and Jefferson 1974:702). But in the second turn constructional unit of this answer turn (lines 22-41), there are two references to Meese (line 29; lines 31-32), and each is device-implicative.

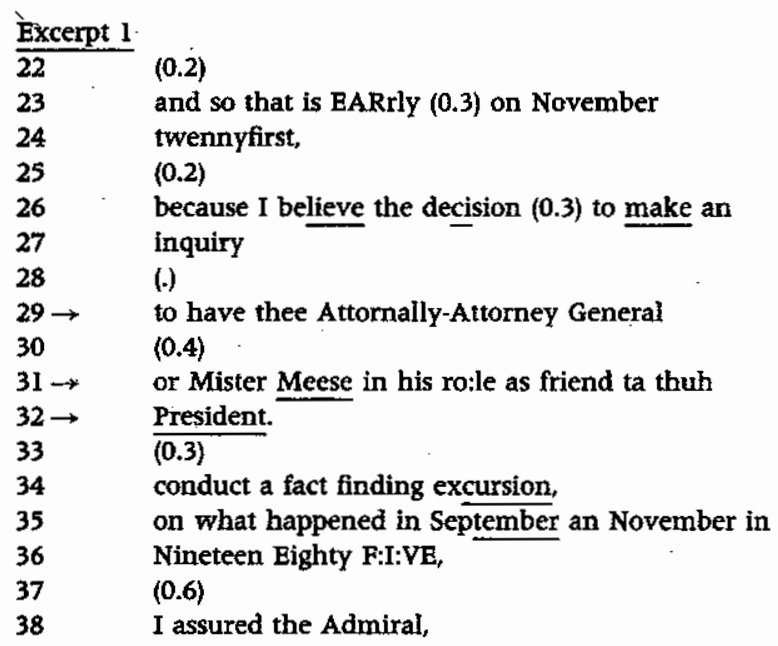

4. The speaker marks this change of "activity descriptions" as a repair by repeating the word that frames the two alternative descriptions ("to", lines 26, 29), as well as by the use of the word "or" between the two alternatives (line 31). Schematically, the repair looks like this:

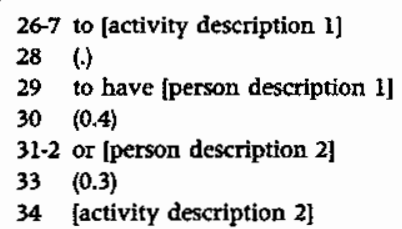

For other examples of marking or "locating" a repairable, see Schegloff, Jefferson, and Sacks (1977), especially section 5.21. 

$39 \quad(0.3)$
40 don't worry, (0.4) its a:ll taken care of.
$41 \quad(0.2)$

Once the witness has referred to the person with a category, which is by definition deviceimplicative, any move to eliminate that device's implicativeness must be achieved by the interactants. One way that the initial device's implicativeness can be eliminated is by offering an alternative device. The witness's repair of his original formulation ("thee . . . Attorney General") with the recognitional ("Mister Meese") plus category appendor ("in his ro:le as") plus categorical reference ("friend ta thuh President") is an example of that procedure.

A few minutes later, the interactants come back to this same topic:

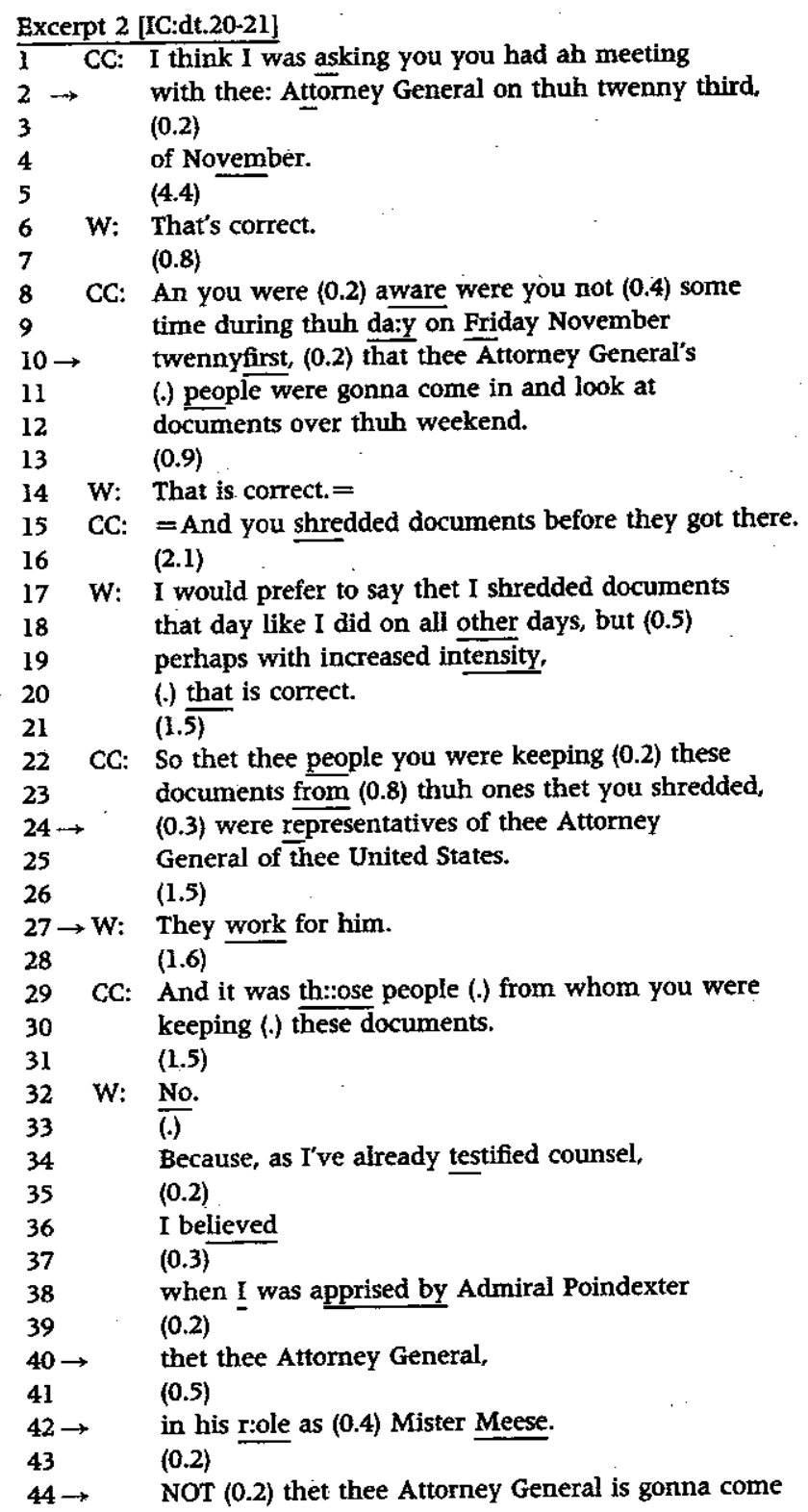




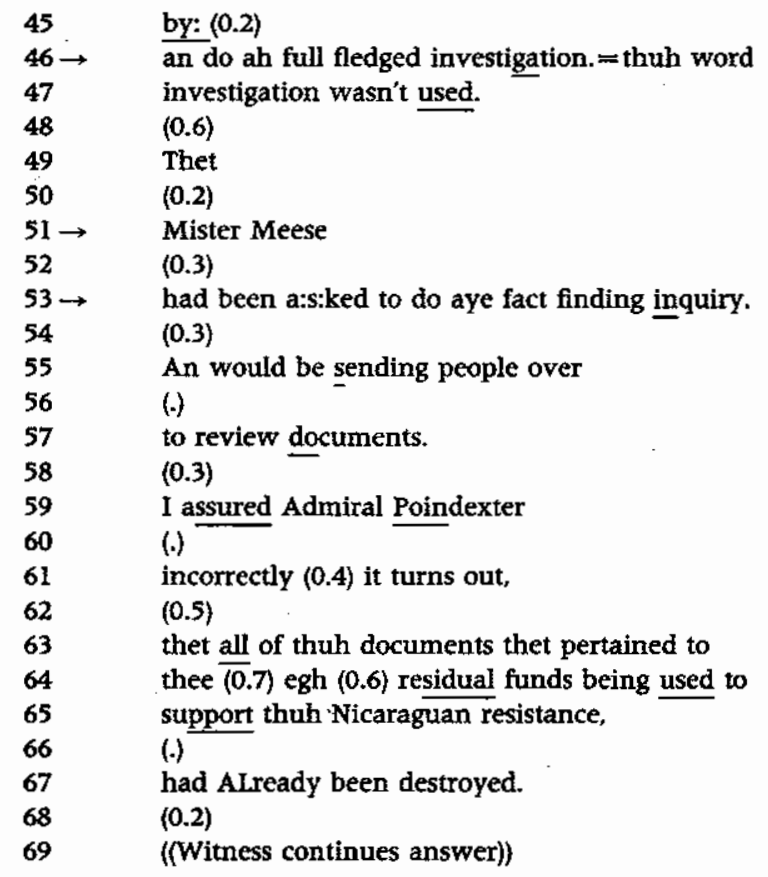

In this "line of questioning" (Atkinson and Drew 1979), the witness's first two answers are unmitigated agreements with the preference built into the questions. ${ }^{5}$ That is, both questions propose a state of affairs that the witness is asked to confirm or deny, and they are formulated in a manner that prefers confirmation.

At line 15 the counsel first formulates a question that is hearable as an accusation:

$15 \rightarrow \mathrm{CC}:=$ And you shredded documents before they got there.

$16 \cdot(2.1)$

Rather than simply agreeing, as in the prior two answers, the witness reformulates the action asked about, and confirms his own reformulation:

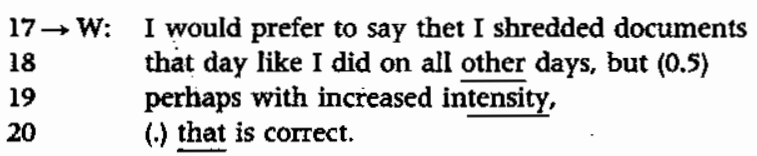

At lines 22-26, the counsel attempts to draw a conclusion from the previous series of questions and answers:

22 CC: So thet thee people you were keeping (0.2) these

23 documents from $(0.8)$ thuh ones thet you shredded,

$24 \rightarrow \quad$ (0.3) were representatives of thee Attorney

25 General of thee United States.

$26 \quad(1.5)$

The conclusion that the questioner issues to the witness for confirmation or denial hinges on the referential formulation of the people who were sent to look at documents in the witness's office: "representatives of the Attorney General of the United States." In asking this

5. The concept of preference is discussed by Sacks ([1973] 1987), Davidson (1984), Pomerantz (1984a, 1984b), and Schegloff (1988b). 
question, the committee counsel treats the matter of how these people should be formulated as consequential. In the witness's response, he too treats this question as consequential, both by withholding confirmation of the question as well as by reformulating the reference phrase in his turn:

$$
27 \rightarrow \mathrm{W} \text { : They work for him. }
$$

The witness, with this response (line 27), shifts the relevant device through which these people, and their activities, should be seen. By reformulating "representatives of thee Attorney General of thee United States" as people who "work for him," it becomes possible to hear their actions ("look[ing] at documents," lines 11-12) as done in an unofficial capacity.

Having received a reformulation rather than a confirmation from the witness, the counsel recycles his question in shortened form:

$$
\begin{aligned}
& 29 \text { CC: And it was th::ose people (.) from whom you were } \\
& 30 \text { keeping (.) these documents. }
\end{aligned}
$$

Again, the question is formulated to elicit a confirmation or denial, with confirmation being the response preferred by the formulation of the question (Sacks 1987).

Throughout this series of questions and answers, the counsel has referred to "the Attorney General," "the Attorney General's people," and "representatives of thee Attorney General of thee United States". By using these categories the counsel invokes a particular device: members of the Attorney General's office. This can be seen as prefatory to issuing an accusation about the willful destruction of evidence sought by that office, or, more generally, the obstruction of justice.

The witness has gone along with these formulations until the accusatory question (lines 22-25) elicits from him the reformulation without confirmation: "they work for him." In his long answer to the reformulated accusation (lines 29-30), the witness refers to Meese as "thee Attorney General" (line 40). Reconsider the following central portion of the witness's answer.

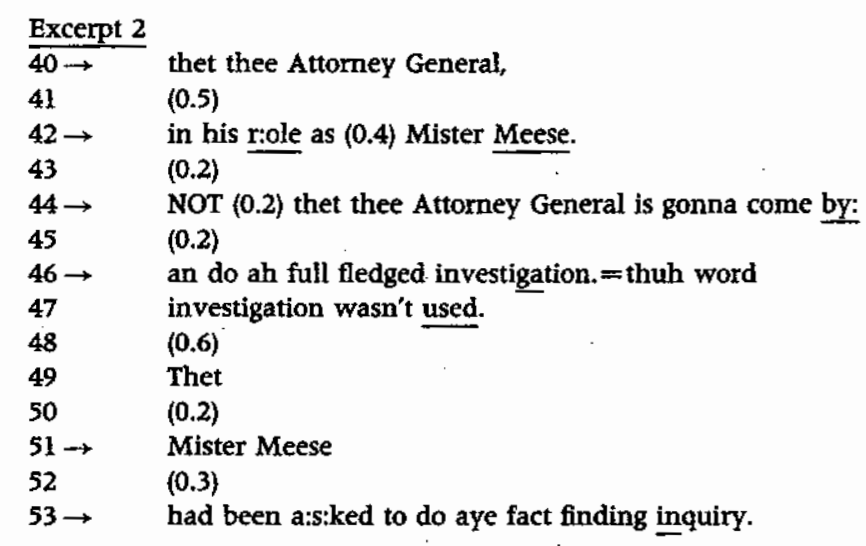

After the witness refers to "the Attorney General," he attempts a category-shift via the same technique used in data excerpt one. By using the category-appendor phrase "in his role as," the witness is attempting to shift off of the device implicated by the category he has just employed. But after the category appendor phrase, the witness places not an alternate category, which could implicate an alternate device, but a recognitional, "Mister Meese" (line 42). Here are the relevant segments from the two excerpts:

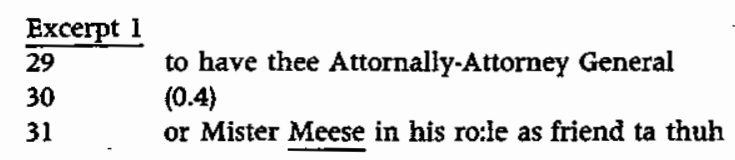




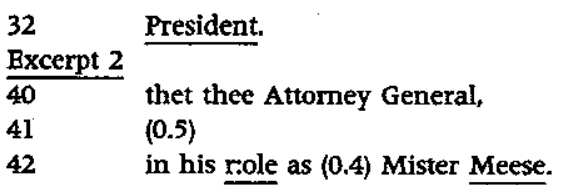

The attempted category-shift in excerpt two, above, is treated by the witness as inadequate, and he abandons that attempt and produces a reference repair:

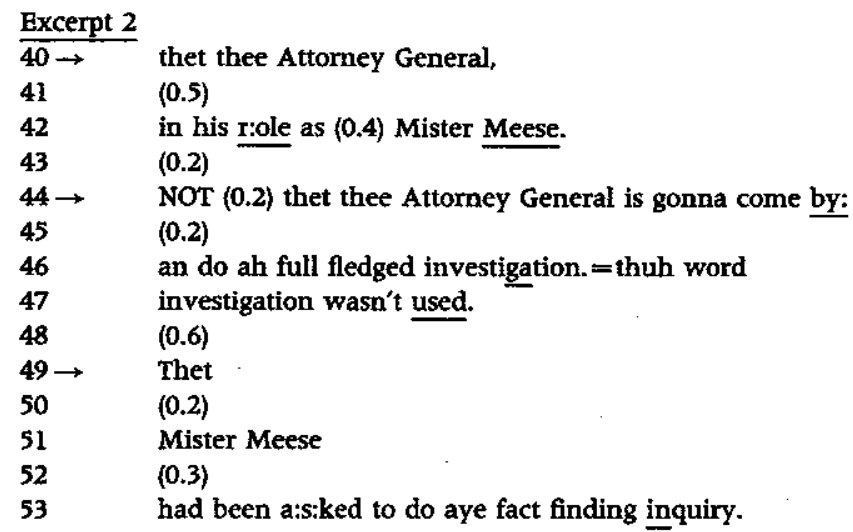

Specifically, the witness produces a repair initiation, in which he negates the category he originally used ("NOT (0.2) thet thee Attorney General"), as well as an action description that he had not used ("ah full fledged investigation."). Indeed, the negation of the action description, "NOT (0.2) thet thee attorney general is gonna come by: $(0.2)$ an do ah full fledged investigation. $=$ thuh word investigation wasn't used" (lines 44-47), is a vehicle through which the person description can be corrected in an embedded fashion (Jefferson 1987). By recycling the term "thet" (line 44), he marks what follows as a repair of what followed the original "thet,"

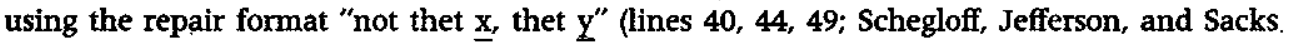
1977). That is, the witness used the occasion of directly negating an action description to lessdirectly negate his prior person description. Thus "Mister Meese," a recognitional term, is used to replace "the Attorney General," a device-implicative category. But the recognitional term is not successful in replacing the category term until the device implied by the original category is somehow negated (lines 44-47). Via this technique, the implication of the category device "position in government" is eliminated, thus a subsequent recognitional can be used to reference the person. After the device implicativeness of a category is removed, a recognitional can again become an adequate free-standing referent.

The phrase "in his role as" is a specific instance of a general category/device shifting technique. Interactants need not use the word "role" to do this shifting work. The data segment below is part of a tape-recorded conversation from the Nixon white House during the Watergate affair:

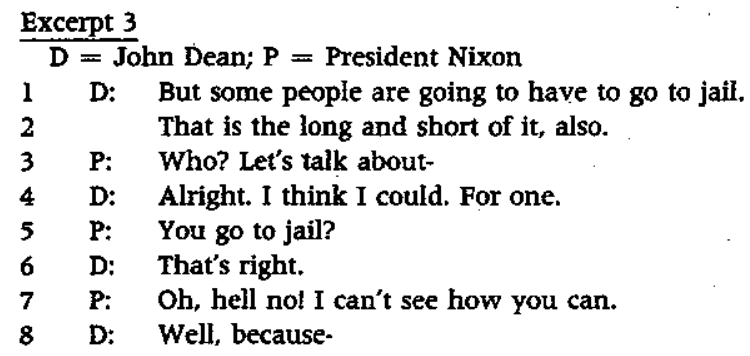


9 P: I can't see how. Let me say I can't see how a

10 legal case could be made against you, John.

Il D: It would be tough but, you know, I can see people

12 pointing fingers. You know, to get it out of

13 their own, put me in an impossible position. Just

14 really give me a (unintelligible)).

15 P: Oh no! Let me say I got the impression here- But

16 just looking at it from a cold legal standpoint:

$17 \rightarrow \quad$ you are a lawyer, you were a counsel, doing what

$18 \rightarrow \quad$ you did as counsel. You were not- What would you

19 go to jail for?

20 D: The obstruction of justice.

21 P: The obstruction of justice?

22 D: That is the only one that bothers me.

23 P: Well, I don't know. I think that one. I feel it

24 could be cut off at the pass, maybe, the

25 obstruction of justice (The Washington Post 1974:1.16-17).

In lines 17-18 above, President Nixon is arguing that Dean need not worry about going to jail for his actions, because those actions were performed "as counsel." More generally, this excerpt suggests that how an actor is described is oriented to by interactants as partially constitutive of his or her action.

A second brief excerpt comes from one of President Bush's press conferences reported in The New York Times (1990:C15):

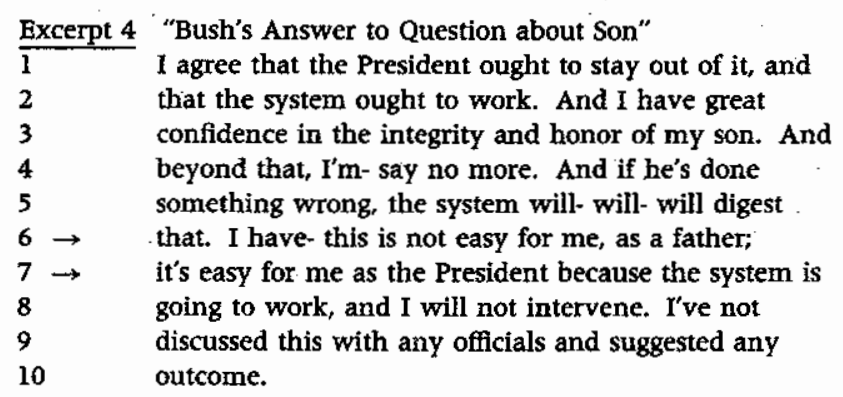

Speaking of his son's alleged involvement in a savings and loan scandal, President Bush makes two statements regarding how he feels about the situation (lines 6-7), but he carefully marks the guise under which each statement is uttered ("as a father"; "as the President"). Bush thus displays that the way his utterances will be heard is tied to the capacities in which he expresses them. Again, we see evidence that interactants are oriented to the partially constitutive character of person and action descriptions. Along with this orientation comes the need to use role as an interactional device in order to display to others (and thereby partially constitute) the guise through which a particular action is performed and, in fact, what sort of action it is.

In both excerpt 3 (lines 17-18) and excerpt 4 (lines 6-7), the word "as" does the work of category-appendor, work done in excerpts 1 and 2 by the phrase "in his role as." Again, member use of the word "role" is not necessary to the analysis. Instead, what is important is the general technique that interactants use to shift off of an initial reference term, where that term implicates a particular categorization device, and how they are able to introduce a new reference term, thus "deleting" the original device.

Category shifting is a way that interactants sequentially delete or "bury" the relevance of a particular categorization device. This becomes a crucial resource when there is an interactional contest regarding what motives should be attributed to an actor (cf. Drew forthcoming). 
What any given action is taken to mean, as well as what sorts of persons interactants are, is based on the interpretive framework socially produced and sustained in ongoing interaction (cf. Mills [1940] 1967:355-56). Category shifting in which people in interaction use the concept role is one kind of interactional work through which members "impute" and "avow" their motives as well as define just what kinds of actions theirs' and others' are.

\section{"Role" as Resource and Topic}

By examining actual conversations where people used the concept role, we found that interactants' descriptions, formulations, and references are themselves part and parcel of the social world they are used to describe. Put more generally, descriptions themselves are social acts. Garfinkel (1967), Sacks (1963, 1964-72, 1972a, 1972b, 1989), Garfinkel and Sacks (1970), and Heritage (1984) have shown in great detail how talk within an interaction is co-constitutive of that self-same interaction. This point also has been nicely demonstrated with respect to plea bargaining sessions and chats among acquainted and unacquainted dyads (Maynard 1984; Maynard and Wilson 1980; and Maynard and Zimmerman 1984).

By treating role as a topic for social scientific analysis rather than only a resource we have seen that person and action categorizations performed in a Congressional hearing can be used to formulate and dodge accusations. We also have seen that a powerful technique in this category shifting work is lay usage of the concept role. This analysis also extends $\mathrm{C}$. Wright Mills' ([1940] 1967) concern with the empirical study of vocabularies of motive. Mills called for the study of motives as social phenomena. By seeing how the concept role is used as a lay device for shifting categories, we have uncovered part of the specific interactional "machinery" (Sacks 1984) that provides for the social organization of motives. Because interactants demonstrably orient to the constitutive character of person and action descriptions, they require the category/device shifting techniques analyzed above. In just these ways, interactants display to others, and thereby partially constitute, the guise through which a particular action is performed, as well as the very character and intelligibility of that performed action.

\section{References}

Atkinson, J. Maxwell, and Paul Drew

1979 Order in Court: The Organization of Verbal Interaction in Judicial Settings. Atlantic Highlands, N.J.: Humanities Press.

Atkinson, J. Maxwell, and John Heritage

1984 Structures of Social Action: Studies in Conversation Analysis. Cambridge: Cambridge University Press.

Blumer, Herbert

1969 Symbolic Interactionism. Englewood Cliffs, N.J.: Prentice Hall.

Clayman, Steven

1987 "Generating news: the interactional organization of news interviews." Ph.D. dissertation, University of California, Santa Barbara, Calif.

1988 "Displaying neutrality in television news interviews." Social Problems 35:474-92.

Coleman, James S.

1970 "Social inventions." Social Forces 49:163-73.

Davidson, Judy

1984 "Subsequent versions of invitations, offers, requests, and proposals dealing with potential or actual rejection." In Structures of Social Action, ed. J. Maxwell Atkinson and John Heritage, 102-28. Cambridge: Cambridge University Press. 
Drew, Paul

1984 "Speakers' reportings in invitation sequences." In Structures of Social Action, ed. J.

Maxwell Atkinson and John Heritage, 129-51. Cambridge: Cambridge University Press.

Forth- "Disputes in courtroom cross-examination: contrasting versions in a rape trial." In Talk coming at Work, ed. Paul Drew and John Heritage. Cambridge: Cambridge University Press.

Garfinkel, Harold

1967 Studies in Ethnomethodology. Bnglewood Cliffs, N.J.: Prentice-Kall.

Garfinkel, Harold, and Harvey Sacks

1970 "On formal structures of practical actions." In Theoretical Sociology, ed. John C.

Gidens, Anthony McKinney and Edward A. Tiryakian, 338-66. New York: Appleton-Century-Crofts.

1984 The Constitution of Society: Outline of the Theory of Structuration. Berkeley: University of California Press.

Gilbert, w. S.

1917 The Mikado and Other Plays. New York: The Modern Library.

Goffman, Erving

1959 The Presentation of Self in Everyday Life. Garden City, N.Y.: Doubleday Anchor.

1981 Forms of Talk. Philadelphia, Pa.: University of Pennsylvania Press.

Halkowski, Timothy

1990 "Hearing talk: the social organization of a Congressional inquiry." Ph.D. dissertation, Santa Barbara, Calif.: University of California.

Heritage, John

1984 Garfinkel and Ethnomethodology. Cambridge: Polity Press.

Hilbert, Richard

1981 "Toward an improved understanding of 'role." Theory and Society 10:207-26.

Forth- "Role-sets and status sets." In Robert K. Merton: Consensus and Controversy, ed. Jon coming Clark, Sohan Modgil, and Celia Modgil. Sussex, England: Falmer Press.

Jefferson, Gail

1987 "On exposed and embedded correction in conversation." In Talk and Social Organization, ed. Graham Button and John Lee, 86-100. Clevedon, England: Multilingual Matters.

Kantorowitz, E. H.

1957 The King's Two Bodies: A Study in Medieval Political Theology. Princeton, N.J.:

Linton, Ralph Princeton University Press.

1936 The Study of Man. New York: Appleton-Century.

Maynard, Douglas

1984 Inside Plea Bargaining. New York: Plenum Press.

Maynard, Douglas, and Thomas P. Wilson

1980 "On the reification of social structure." In Current Perspectives in Social Theory: A Research Annual, ed. Scott McNall and Gary Howe, 282-322. Greenwich, Conn.: JAI Press.

Maynard, Douglas, and Don H. Zimmerman

1984 "Topical talk, ritual, and the social organization of relationships." Social Psychology Quarteriy 47:301-16.

Mead, George H.

1934. Mind, Self, and Society. Chicago: University of Chicago Press.

Merton, Robert K.

1957 "The role set: problems in sociological theory." British Journal of Sociology 8:6-20.

1968 Social Theory and Social Structure. New York: The Free Press.

Mills, C. Wright

[1940] "Situated actions and vocabularies of motive." In Symbolic Interaction: A Reader in

1967 Social Psychology, ed. Jerome Manis and Bernard Meltzer, 355-66. Boston: Allyn and Bacon.

Moerman, Michael

1988 Talking Culture: Ethnography and Conversation Analysis. Philadelphia, Pa.: University of Pennsylvania Press. 
New York Times

1990 "Bush's answer to question about son." July 12, Section C:15.

Parsons, Talcott

1951 The Social System. New York: The Free Press.

1968 The Structure of Social Action. New York: The Free Press,

Pomerantz, Anita

1984a "Agreeing and disagreeing with assessments: some features of preferred/dispreferred turn shapes." In Structures of Social Action, ed. J. Maxwell Atkinson and John Heritage, 57. 101. Cambridge: Cambridge University Press.

1984 b "Pursuing a response." In Structures of Social Action, ed. J. Maxwell Atkinson and John Sacks, Harvey Heritage, 152-64. Cambridge: Cambridge University Press.

1963 "On sociological description." Berkeley Journal of Sociology 8:1-16.

1964-72 Unpublished lectures. Transcribed and edited by Gail Jefferson. Irvine, Calif.: University of California.

1972a "An initial investigation of the usability of conversational data for doing sociology." In Studies in Social Interaction, ed. David Sudnow, 31-74. New York: Free Press.

$1972 b$ "On the analyzability of stories told by children." In Directions in Sociolinguistics, ed. John Gumperz and Dell Hymes, 325-45. New York: Holt, Rinehart and Winston.

1979 "Hotrodders: a revolutionary category." In Everyday Language: Studies in Ethnomethodology, ed. George Psathas, 7-14. New York: Irvington Press.

1984 "Notes on methodology." In Structures of Social Action, ed. J. Maxwell Atkinson and John Heritage, 21-27. Cambridge: Cambridge University Press.

[1973] "On the preference for agreement and contiguity in the organization of sequences in

1987 conversation." In Talk and Social Organizațion, ed. Graham Button and John R. E. Lee, 54-69. Clevedon, England: Multilingual Matters.

1989 The 1964-1965 lectures. Human Studies 12:183-410.

Sacks, Harvey, and Emanuel Schegloff

1979 "Two preferences in the organization of reference to persons in conversation and their interaction." In Everyday Language: Studies in Ethnomethodology, ed. George Psathas, 15-21. New York: Invington Press.

Sacks, Harvey, Emanuel Schegloff, and Gail Jefferson

1974 "A simplest systematics for the organization of turn-taking for conversation." Language 50:696.735.

Schegloff, Emanuel

1988a "Description in the social sciences I." Papers in Pragmatics 2:1-24.

1988b "On an actual virtual servo-mechanism for guessing bad news: a single case conjecture." Social Problems 35:442-57.

Schegloff, Emanuel, Gail Jefferson, and Harvey Sacks

1977 "The preference for self-correction in the organization of repair in conversation."

Schutz, Alfred Language 53:361-82.

[1962] Collected Papers, Vol. I: The Problem of Social Reality. The Hague: Martinus Nijhoff. 1982

Smith, Dorothy

1974 "The ideological practice of sociology." Catalyst 8:39-54.

Stryker, Sheldon

1980 Symbolic Interactionism: A Social Structural Vision, Menlo Park, Calif: Benjamin Cummings.

Turner, Ralph H.

1962 "Role-taking: process versus conformity." In Human Behavior and Social Processes, ed. Arnold Rose, 20-40. New York: Houghton Mifflin.

The Washington Post, ed.

1974 The Presidential Transcripts. New York: The Washington Post.

Zimmerman, Don H., and Melvin Pollner

1970 "The everyday world as phenomenon." In Understanding Everyday Life, ed. Jack Douglas, 80-103. Chicago: Aldine. 